\section{OAK RIDGE \\ NATIONAL LABORATORY}

MANAGED BY UT-BATTELLE

FOR THE DEPARTMENT OF ENERGY

\section{Mission MOX Fuel Physics Design- Preliminary Equilibrium MOX Assembly Design and Expected Operating Power for Existing Balakovo Fuel Management Scheme}

A. M. Pavlovichev

A Russian Contribution to the Fissile Materials Disposition Program

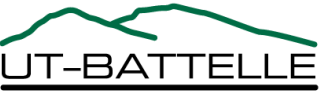




\section{DOCUMENT AVAILABILITY}

Reports produced after January 1, 1996, are generally available free via the U.S. Department of Energy (DOE) Information Bridge:

Web site: http://www.osti.gov/bridge

Reports produced before January 1, 1996, may be purchased by members of the public from the following source:

National Technical Information Service

5285 Port Royal Road

Springfield, VA 22161

Telephone: 703-605-6000 (1-800-553-6847)

TDD: $703-487-4639$

Fax: 703-605-6900

E-mail: info@ntis.fedworld.gov

Web site: http://www.ntis.gov/support/ordernowabout.htm

Reports are available to DOE employees, DOE contractors, Energy Technology Data Exchange (ETDE) representatives, and International Nuclear Information System (INIS) representatives from the following source:

Office of Scientific and Technical Information

P.O. Box 62

Oak Ridge, TN 37831

Telephone: $865-576-8401$

Fax: 865-576-5728

E-mail: reports@adonis.osti.gov

Web site: http://www.osti.gov/contact.html

This report was prepared as an account of work sponsored by an agency of the United States Government. Neither the United States government nor any agency thereof, nor any of their employees, makes any warranty, express or implied, or assumes any legal liability or responsibility for the accuracy, completeness, or usefulness of any information, apparatus, product, or process disclosed, or represents that its use would not infringe privately owned rights. Reference herein to any specific commercial product, process, or service by trade name, trademark, manufacturer, or otherwise, does not necessarily constitute or imply its endorsement, recommendation, or favoring by the United States Government or any agency thereof. The views and opinions of authors expressed herein do not necessarily state or reflect those of the United States Government or any agency thereof. 


\title{
MISSION MOX FUEL PHYSICS DESIGN-PRELIMINARY EQUILIBRIUM MOX ASSEMBLY DESIGN AND EXPECTED OPERATING POWER FOR EXISTING BALAKOVO FUEL MANAGEMENT SCHEME
}

\author{
A. M. Pavlovitchev
}

Date Published: September 2001

\author{
Prepared by \\ Russian Research Center "Kurchatov Institute" \\ Institute of Nuclear Reactors \\ under subcontract 85B-99398V \\ Funded by \\ Office of Fissile Materials Disposition \\ U.S. Department of Energy \\ Prepared for \\ Computational Physics and Engineering Division \\ OAK RIDGE NATIONAL LABORATORY \\ Oak Ridge, Tennessee 37831 \\ managed by \\ UT-BATTELLE, LLC \\ for the \\ U.S. DEPARTMENT OF ENERGY \\ under contract DE-AC05-00OR2272
}




\title{
Russian Research Center "Kurchatov Institute" \\ Institute of Nuclear Reactors \\ VVER Division
}

Joint U.S. / Russian Project to Update, Verify and Validate Reactor Design/Safety Computer Codes

Associated with Weapons-Grade Plutonium Disposition in WER Reactors

\author{
MISSION MOX FUEL PHYSICS DESIGN \\ Preliminary Equilibrium MOX Assembly Design \\ and Expected Operating Power for Existing Balakovo Fuel \\ Management Scheme
}

General Order 85B-99398V

(Report)

Project Manager

A.M.Pavlovichev

Executed by

A.M.Pavlovichev

Moscow 2000 
Acronyms

\begin{tabular}{|c|c|}
\hline Explanation & Acronyms \\
\hline Absorbing Rod & $\mathrm{AR}$ \\
\hline Beginning of Fuel Cycle & $\mathrm{BOC}$ \\
\hline Burnable Poison Rod & BPR \\
\hline Doppler Temperature Coefficient & DTC \\
\hline Effective Full Power Day & EFPD \\
\hline Effective Full Power Hour & EFPH \\
\hline End of Fuel Cycle & EOC \\
\hline Kurchatov Institute & KI \\
\hline Institute of Physic and Power Engineering (Obninsk) & IPPE \\
\hline Russian authority for nuclear safety & GAN \\
\hline Light Water Reactor & LWR \\
\hline Minimum Controllable Reactor Power Level & $\mathrm{MCL}$ \\
\hline Moderator Density Coefficient & MDC \\
\hline Mixed Oxide (uranium-plutonium fuel) & MOX \\
\hline Moderator Temperature Coefficient & MTC \\
\hline Nuclear Power Plant & NPP \\
\hline Control Rod & $\mathrm{CR}$ \\
\hline Pressurised Water Reactor & PWR \\
\hline Repeat Criticality Temperature & RCT \\
\hline Reactor Control and Protection System & CPS \\
\hline Fuel Assembly & FA \\
\hline Zirconium fuel for cladding & ZG \\
\hline Zirconium Guide Tube & ZGT \\
\hline Uranium Oxide Fuel & UOX \\
\hline Uranium-Gadolinium Fuel & UGF \\
\hline Russian water-water reactor & VVER \\
\hline
\end{tabular}




\section{SUMMARY}

The Document issued according to Work Release 02. P. 99-3a and 99-3b presents neutronics calculations of $30 \%$ MOX fuelled core of VVER-1000. Two options of equilibrium core with gadolinium burnable poison rods are calculated. Comparison is performed with VVER-1000 Uranium core of Project V-320. 


\section{Contents}

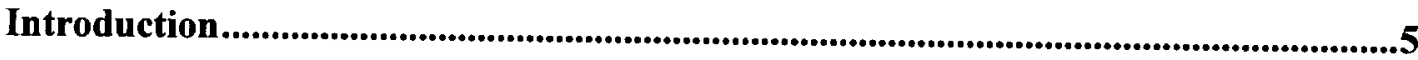

Fuel Cycle with 1/3 MOX Fuel ...............................................................................8

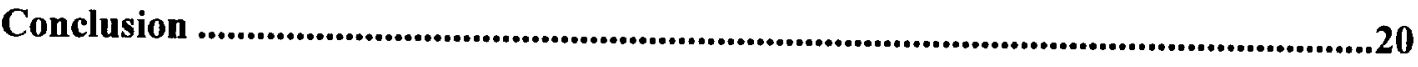






\section{Introduction}

Among various versions of excess weapons-grade plutonium handling the most preferred in Russia is its burning in power reactors. This is accounted for by the desire to utilize the power value of weapons-grade plutonium and the potentialities of the existing nuclear industry complex.

In Russia the versions of burning weapons-grade plutonium in the VVER-, BN-, and HTGR-type power reactors are being developed. However the analysis of the current structure of nuclear power and the energy strategy reveals that in the coming years the VVER-1000type (designs B-320 and B-392) as well as the VVER-640 reactor (design B-407) now under development appear to be the most promising for this purpose. The experience with the use of mixed uranium/plutonium fuel in the LWR, gained in the West and the preliminary studies carried out in Russia [1]-[3] show that weapons-grade plutonium may be actually used as fuel for the Russian VVER reactors.

At present Russia has 7 operating VVER-1000 of total installed capacity 7 GWe, 11 reactors of this type are in operation in Ukraine, and 2 - in Bulgaria. Before 2003 it is planned to put into operation 2 VVER-1000 units more in Russia and at least 2 units in Ukraine.

In their designs the cores of all VVER-1000 reactors are nearly the same. The most distinctive difference consists in the number of the control rods:

- 109 at Novo-Voronezh NPP-5;

49 at South-Ukrainian NPP-1;

61 in the rest of the operating VVER-1000 reactors.

The designed fuel cycle (B-320) of the operating VVER-1000 [4], developed in the late $70 \mathrm{~s}$ has the following characteristic features: three-year core life, OUT-IN-IN core design, stainless steel as structural material for fuel assemblies (guide tubes and grids), removable burnable boron poisons. At present the most of VVER-1000 reactors are operating using the B-320 fuel cycle. Therefore it is used as referenced cycle within the frame of these investigations. The part 2 of this report contains description of the main characteristics of the B-320 fuel cycle.

At present the extensive efforts are under way in Russia on advance of the VVER1000 fuel cycle [5]. The distinctive features of the advanced fuel cycles are the following:

- fuel assemblies with zirconium grids and guide tubes;

- uranium-gadolinium fuel as a burnable poison;

- fuel rods with reduced diameter of the center holes in fuel pellets;

- control rod consists of two parts: the upper one contains $\mathrm{B}_{4} \mathrm{C}$ and the lower one $\mathrm{Dy}_{2} \mathrm{O}_{3} * \mathrm{TiO}_{2}$;

- low leakage loading pattern.

The advanced fuel cycle of VVER-1000 has considerable advantages:

- increase in the control rod system efficiency; 
- improved conditions of the reactor vessel performance due to the reduction in the fast neutron flux;

- increase in control rod operational time;

- decrease in the fuel enrichment, which increases the nuclear safety in the phases of enrichment, fabrication of fuel pellets and fuel assemblies.

By present in Russia the basic prerequisites has been established for large-scale implementation of the advanced fuel cycles with improved FAs and the uranium-gadolinium fuel. In particular:

- pilot operation of FAs with UGF is conducted at the Balakovo NPP;

- pilot operation of FAs with ZGs and ZGTs is being carried out at the Balakovo, Kalinin and Zaporozhie NPPs;

- advanced control rods $\left(\mathrm{B}_{4} \mathrm{C}, \mathrm{Dy}_{2} \mathrm{O}_{3} * \mathrm{TiO}_{2}\right)$ have been used at Balakovo, Kalinin and Zaporozhie NPPs;

- in many VVER-1000 reactors the low leakage loading pattern has been successfully used.

It is planned to transform the VVER-1000 reactors into the advanced cycle by the year 2001. Hence by the time of MOX fuel implementation VVER-1000 reactors will be working with advanced fuel cycle.

In Russia the calculation studies of the possible use of reactors- and weapons-grade plutonium in the VVER-1000 type reactors have been carried out for several years. The emphasis is made on the simplest methods of plutonium use in the VVER-1000 fuel cycle: a direct replacement of the uranium fuel by MOX fuel without any serious changes in the core design and in the power unit operating conditions. The studies were carried out for stationary 3 -year fuel cycle with a core life about $7000 \mathrm{EFPH}$. The advanced FA with ZG and ZGT was used.

The investigations of Russian and West specialists showed [1, 2] that the weaponsgrade plutonium is in an intermediate position between uranium fuel and civil plutonium being used in the West from the point of view of neutronics characteristics defining plutonium disposition in LWRs. Therefore the use of MOX fuel results in some changes in the physical safety relating characteristics of a core:

- reduced worth of the control rods, boric acid and burnable poisons;

- reduced effective fraction of delayed neutrons;

- reduced moderator temperature reactivity coefficient at the end of cycle;

- increased pin power peaking factor at the boundary between MOX and UOX FAs that makes necessary to use fuel rods with different contents of plutonium in fuel assembly;

- increased quantity of fission neutrons;

- increased neutron flux sensitivity to local changes of moderator/fuel ratio.

Taking into account the results of preliminary investigations and the analysis of the experience gained in the use of MOX fuel in the western PWRs, the emphasis was made on the advanced VVER-1000 fuel cycle where the fraction of MOX FAs is about $1 / 3$. 
The calculations were carried out with the new code package that has been developed in RRC KI (TVS-M, BIPR-7A, PERMAK-A) [6],[7].

Code TVS-M. The TVS-M code calculates few-group neutron cross sections for cells (fuel rods, absorber rods, burnable absorber rods and other cells) and fuel assemblies as functions of reactor state and fuel burnup for the codes BIPR and PERMAK.

Code BIPR-7A. The code BIPR-7A calculates criticality parameters, reactivity effects and coefficients, control rod worth, three-dimensional power distribution, burnup and refueling processes, xenon and samarium transients and etc in VVER cores.

Code PERMAK-A. The code calculates pin-by-pin power and burnup distribution in VVER cores.

Verification of Russian codes in order to define calculational errors in VVER-1000 MOX fuelled core seems to be very difficult task. No experiments have been carried out in Russia with MOX fuel and there is no experience on its usage in VVER type reactors. Therefore, international co-operation becomes very important at the current stage of codes verification. Some years ago RRC "Kurchatov Institute" together with SRC "Institute of Physic and Power Engineering"(IPPE) and with colleagues from USA, France and Germany, have been engaged in the verification. Besides Russian data on uranium fuel, the results of criticality experiments with plutonium, data on post-reactor studies provided by foreign partners and the results of joint calculations of different test problems are used for verification [8],[9]. 


\section{Fuel Cycle with 1/3 MOX Fuel}

The core is assembled of advanced FAs. Two assembly types are used in the equilibrium fuel cycle - MOX FA with the average fissile plutonium content of $3.43 \%$ and UOX FA with the average $U^{235}$ enrichment of $4.08 \%$ (see Table 1). Uranium-gadolinium fuel rods with the Gd concentration of $5 \%$ and $4 \%$ wt. are used to lower a multiplication ability of
fresh UOX and MOX FAs.

Under equilibrium cycle (loading pattern is given in Fig. 3 ) the number of FAs reloaded is 48 pcs. ( 18 MOX FAs and 30 UOX FAs). MOX FAs operate during 3 cycles in the central part of the core. A part of UOX FAs ( 11 pcs.) operate during 3 cycles in the central part of the core, the rest ones - during 4 cycles and 18 of them during two or three cycles - in the core periphery. Such mode of fuel irradiation allows to minimize the difference between the average and maximum burn-up of fuel in FAs withdrawn. Arrangement of 18 FAs of the last (the fourth) year of operation in the core periphery cells, closest to the reactor vessel, creates the conditions for reducing the fast neutron flux to the vessel and facilitates increasing of shutdown margin.

The equilibrium refuelling scheme and the main core characteristics in the course of burn-up are presented in Fig. 4.

Fuel burn-up averaged over the discharged FAs is $38.8 \mathrm{MWd} / \mathrm{kg}$ ( MOX FAs) and 42.0 MWd/kg (UOX FAs), and maximum one does not exceed $39.3 \mathrm{MWd} / \mathrm{kg}$ ( MOX FAs) and $49.4 \mathrm{MWd} / \mathrm{kg}$ ( UOX FAs). Distribution of fuel burn-up over the core height at the BOC and EOC of cycle is presented in Tables 2 and 3. Figs 5 and 6 illustrate distribution of maximum burn-up of fuel rods and fuel pellets over FAs at the end of cycle.

Reactivity balance while emergency system actuating and reactor cooling is presented in Table 4 for B-320 Project and for MOX fuel cycle. Calculational errors in emergency system effectiveness, temperature and power effects are taken into account. The results show that sub-criticality in UOX and MOX fuel cycles are very close. RCT for EOC in all the considered variants is about $210^{\circ} \mathrm{C}$. It is seen also in Fig. 7 where after scram actuation subcriticality is presented versus coolant temperature (Project B-320 and the MOX fuel cycle).

Fig. 8 illustrates influence of boron isotopic content in ARs on core sub-criticality in MOX fuelled core. Cooling process after scram actuation is considered. Boron-10 content in the upper part of combined absorber was varying from the natural one to $80 \% \mathrm{wt}$. For comparison the results of sub-criticality calculation in UOX core with standard absorbers are also presented in Fig. 8. The presented results show that increasing of Boron-10 content ensures the additional sub-criticality of $1 \%$ and $0.5 \%$ correspondingly for the coolant temperatures of $280^{\circ} \mathrm{C}$ and $120^{\circ} \mathrm{C}$. 
Table 1. Description of Fuel Assemblies for VVER-1000 with 1/3 MOX Fuel

\begin{tabular}{|c|c|c|c|c|c|c|c|c|c|}
\hline \multirow[t]{2}{*}{$\begin{array}{c}\text { Fuel } \\
\text { assembly } \\
\text { type }\end{array}$} & \multicolumn{2}{|c|}{$\begin{array}{c}\text { Averaged } \\
\text { content of fissile } \\
\text { isotopes } \\
\text { [wt \%] }\end{array}$} & \multicolumn{3}{|c|}{$\begin{array}{l}\text { Number of different fuel type rods } \\
\text { and content of fissile isotopes }(\% \mathrm{Wt})\end{array}$} & \multicolumn{3}{|c|}{$\begin{array}{l}\text { Characteristics of Uranium-Gadolinium } \\
\text { Fuel Rods }\end{array}$} & \multirow[t]{2}{*}{$\begin{array}{l}\text { Reference to } \\
\text { Fig. with FA } \\
\text { scheme }\end{array}$} \\
\hline & $\mathrm{U}^{235^{6}}$ & $\mathrm{Pu}^{\mathrm{fiss}} *$ & Type 1 & Type 2 & Type 3 & Number & $\begin{array}{c}\text { Uranium } \\
\text { enrichment } \\
\% \mathrm{Wt} \\
\end{array}$ & $\begin{array}{c}\text { Content of } \\
\text { Gadolinium } \\
\% \mathrm{Wt} \\
\end{array}$ & \\
\hline P2G18 & 0.2 & 3.43 & $\begin{array}{c}234 \\
3.6 \% \mathrm{Pu}^{\text {fiss }} \\
0.2 \% \mathrm{U}^{235} \\
\end{array}$ & $\begin{array}{c}54 \\
2.7 \% \mathrm{Pu}^{\text {fiss }} \\
0.2 \% \mathrm{U}^{235} \\
\end{array}$ & $\begin{array}{c}6 \\
2.4 \% \mathrm{Pu}^{\text {fiss }} \\
0.2 \% \mathrm{U}^{235} \\
\end{array}$ & 18 & 3.6 & 4.0 & Fig.1 \\
\hline U41G6 & 4.08 & - & $\begin{array}{c}240 \\
4.2 \% \mathrm{U}^{235} \\
\end{array}$ & $\begin{array}{c}66 \\
3.7 \% \mathrm{U}^{235} \\
\end{array}$ & - & 6 & 3.3 & 5.0 & Fig. 2 \\
\hline
\end{tabular}


Fig. 1. VVER-1000 Core with 1/3 MOX FAs.

Fuel Assembly Pattern, type-P2G18

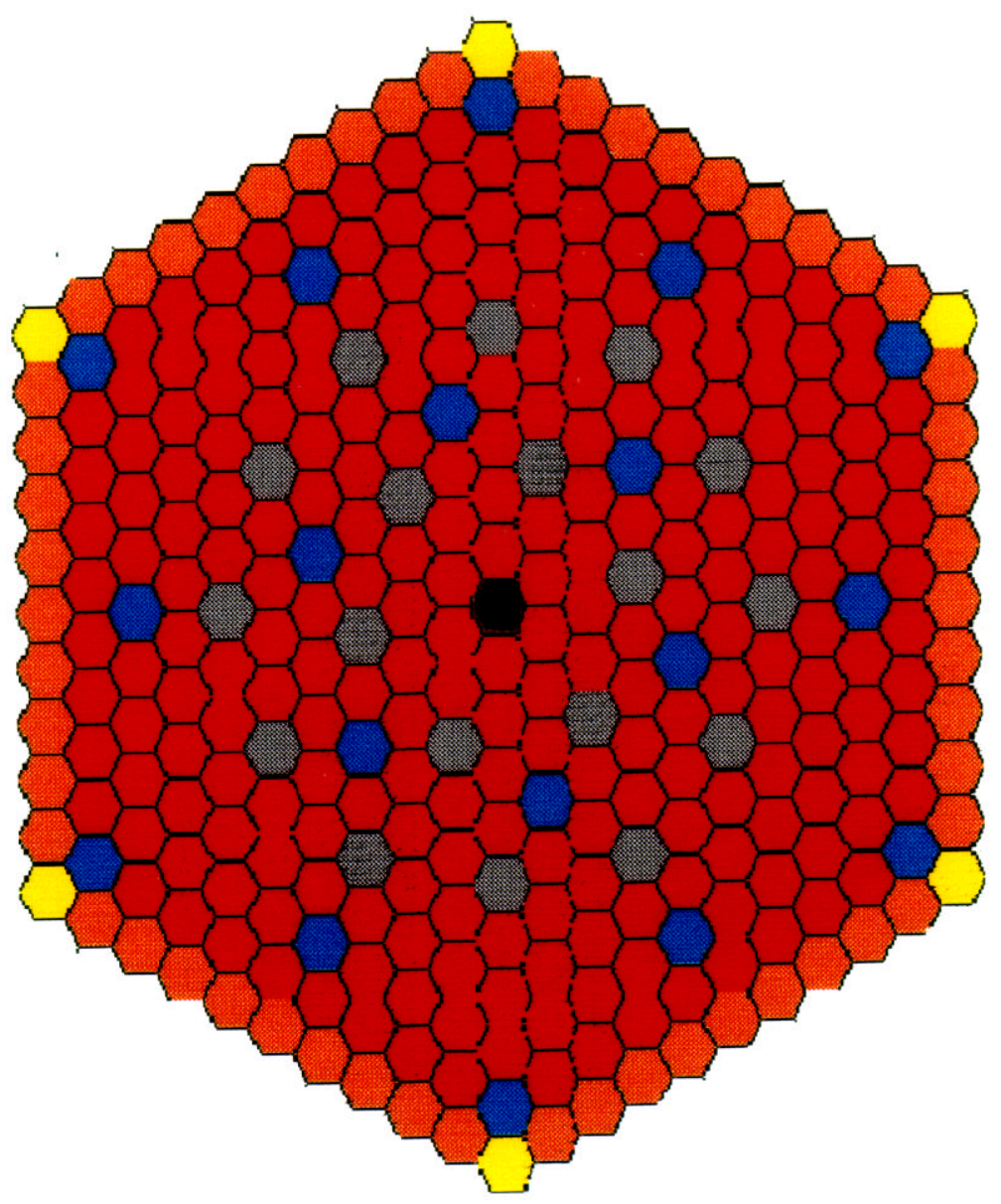

Fuel Rod ( Pu ${ }^{\text {fiss }}-3.6 \%$ )

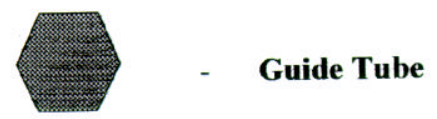

Fuel Rod ( Pu ${ }^{\text {fiss }}-2.7 \%$ )

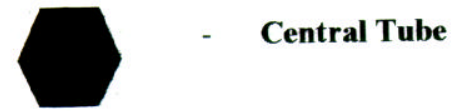

- $\quad$ Fuel Rod ( Pu ${ }^{\text {fiss }}-\mathbf{2 . 4 \%}$ )

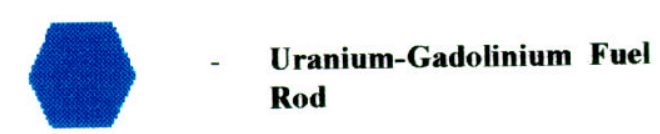


Fig. 2. Uranium Fuel Assembly Pattern, type - U41G6 (4.2/3.7\%)

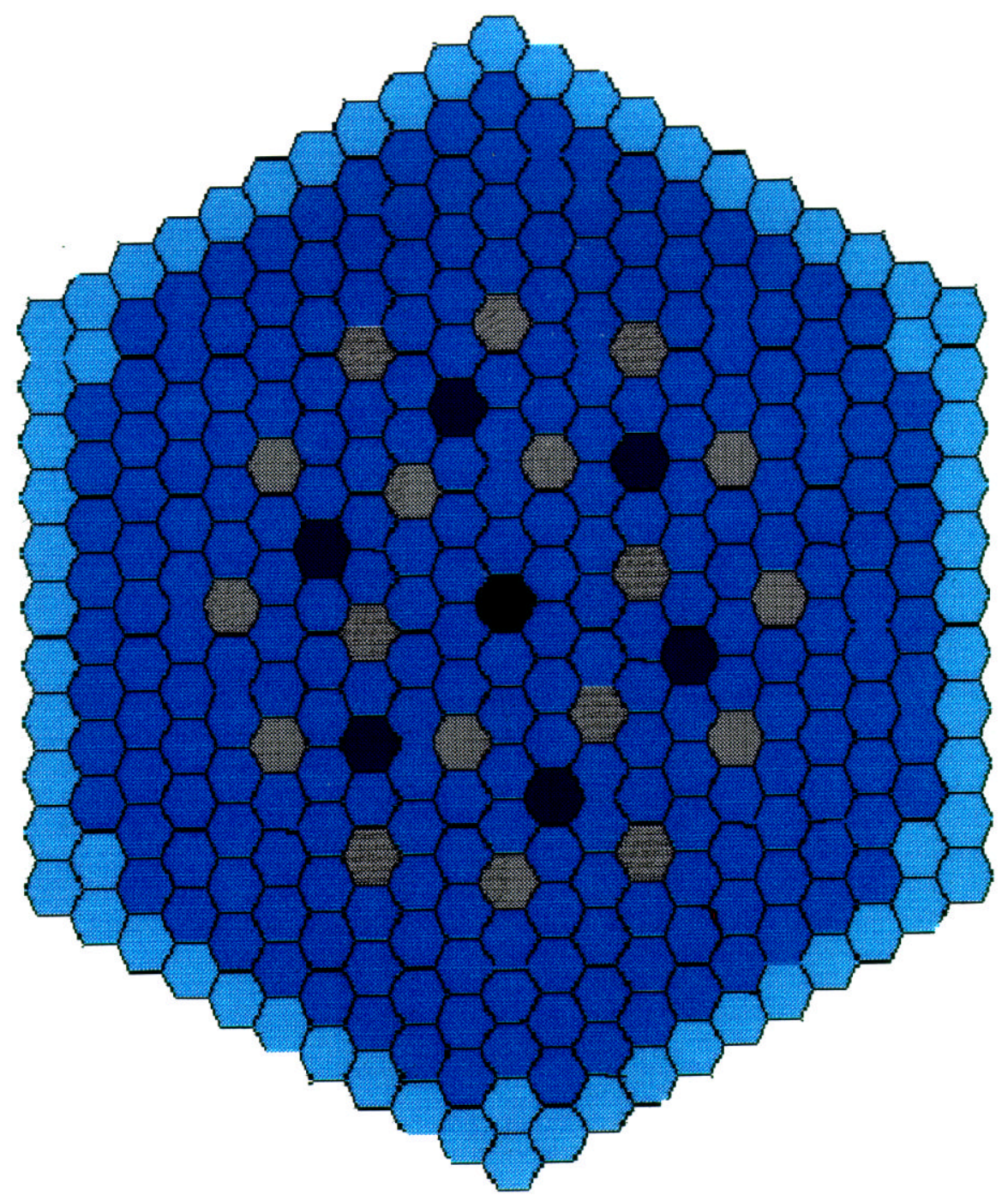

- $\quad$ Fuel $\operatorname{Rod}(U-4.2 \%)$

- $\quad$ Fuel Rod ( U-3.7\%)

- Guide Tube

- Central Tube

- Uranium-Gadelinium Fuel 
Fig. 3. Equilibrium Loading Pattern ( Variant 2)

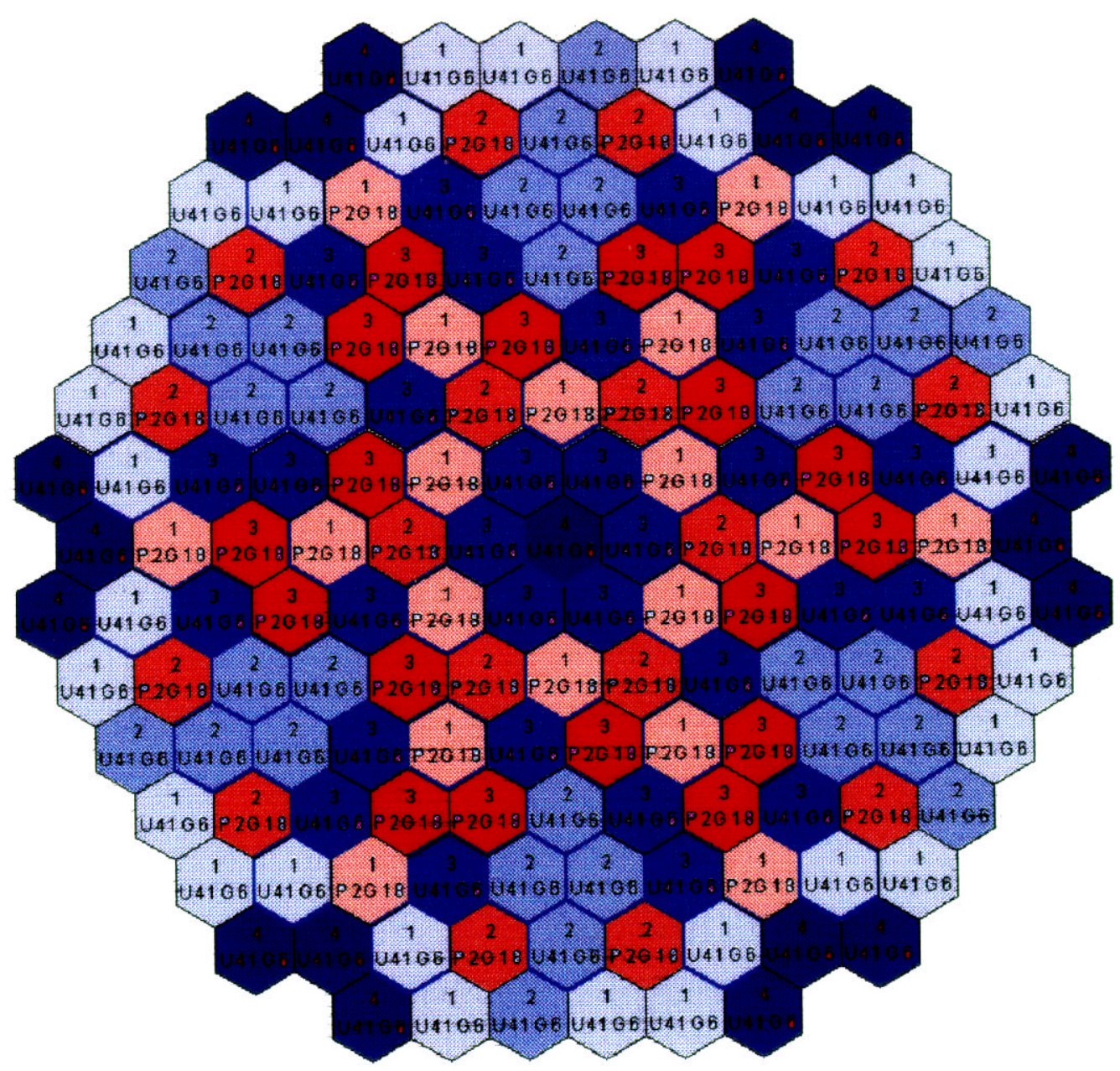




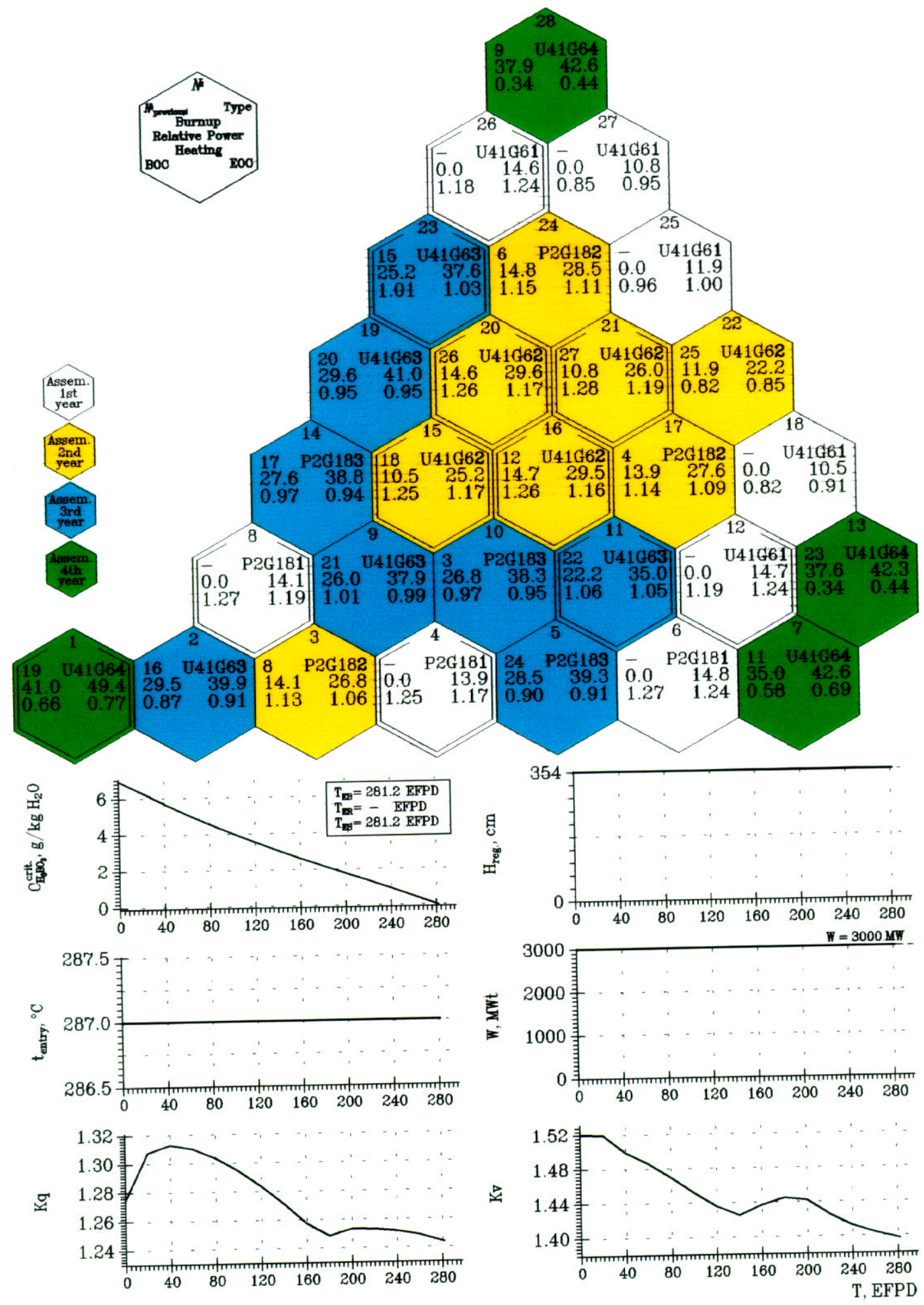

Fig. 4. Variation of the core characteristics in the course of the equilibrium fuel cycle burn-up 
Table 2. Burn-up distribution over FA height

\section{$\mathbf{T}=0.0$ EFPD}

\begin{tabular}{|c|c|c|c|c|c|c|c|c|c|c|c|c|c|c|c|c|c|c|c|}
\hline 1 & 2 & 3 & 4 & 5 & 6 & 7 & 8 & 9 & 10 & 11 & 12 & 13 & 14 & 15 & 16 & 17 & 18 & 19 & 20 \\
\hline 28.0 & 19.2 & 9.4 & 0.0 & 18.2 & 0.0 & 22.4 & 0.0 & 16.2 & 18.3 & 13.4 & 0.0 & 25.4 & 18.3 & 6.1 & 8.8 & 9.4 & 0.0 & 19.3 & 8.8 \\
\hline 40.9 & 29.0 & 14.0 & 0.0 & 27.7 & 0.0 & 34.3 & 0.0 & 25.2 & 26.9 & 21.4 & 0.0 & 37.4 & 27.2 & 10.0 & 14.0 & 13.9 & 0.0 & 29.0 & 13.9 \\
\hline 42.9 & 30.8 & 14.8 & 0.0 & 29.7 & 0.0 & 36.7 & 0.0 & 27.2 & 28.3 & 23.3 & 0.0 & 39.4 & 28.9 & 10.9 & 15.2 & 14.7 & 0.0 & 30.8 & 15.2 \\
\hline 43.4 & 31.3 & 15.0 & 0.0 & 30.3 & 0.0 & 37.3 & 0.0 & 27.8 & 28.6 & 23.8 & 0.0 & 39.9 & 29.3 & 11.3 & 15.6 & 14.8 & 0.0 & 31.4 & 15.6 \\
\hline 43.8 & 31.7 & 15.1 & 0.0 & 30.8 & 0.0 & 37.8 & 0.0 & 28.2 & 28.8 & 24.2 & 0.0 & 40.3 & 29.6 & 11.5 & 15.9 & 15.0 & 0.0 & 31.8 & 15.9 \\
\hline 44.3 & 32.2 & 15.3 & 0.0 & 31.2 & 0.0 & 38.3 & 0.0 & 28.6 & 29.0 & 24.6 & 0.0 & 40.7 & 30.0 & 11.7 & 16.3 & 15.1 & 0.0 & 32.2 & 16.3 \\
\hline 44.8 & 32.6 & 15.4 & 0.0 & 31.7 & 0.0 & 38.8 & 0.0 & 29.1 & 29.3 & 25.0 & 0.0 & 41.1 & 30.4 & 11.9 & 16.6 & 15.3 & 0.0 & 32.7 & 16.6 \\
\hline 45.2 & 33.1 & 15.6 & 0.0 & 32.1 & 0.0 & 39.3 & 0.0 & 29.5 & 29.5 & 25.3 & 0.0 & 41.5 & 30.7 & 12.1 & 16.9 & 15.4 & 0.0 & 33.1 & 16.9 \\
\hline 44.6 & 32.5 & 15.2 & 0.0 & 31.3 & 0.0 & 38.3 & 0.0 & 28.8 & 28.9 & 24.5 & 0.0 & 40.9 & 30.0 & 11.6 & 16.4 & 15.1 & 0.0 & 32.5 & 16.3 \\
\hline 32.3 & 22.9 & 10.7 & 0.0 & 21.9 & 0.0 & 26.6 & 0.0 & 19.7 & 20.6 & 16.3 & 0.0 & 29.3 & 21.3 & 7.5 & 11.0 & 10.7 & 0.0 & 23.0 & 10.9 \\
\hline 21 & 22 & 23 & 24 & 25 & 26 & 27 & 28 & & & & & & & & & & & & \\
\hline 6.2 & 6.9 & 16.6 & 9.2 & 0.0 & 0.0 & 0.0 & 25.0 & & & & & & & & & & & & \\
\hline 10.2 & 11.3 & 24.9 & 14.2 & 0.0 & 0.0 & 0.0 & 37.4 & & & & & & & & & & & & \\
\hline 11.3 & 12.5 & 26.4 & 15.3 & 0.0 & 0.0 & 0.0 & 39.7 & & & & & & & & & & & & \\
\hline 11.7 & 12.8 & 26.8 & 15.7 & 0.0 & 0.0 & 0.0 & 40.3 & & & & & & & & & & & & \\
\hline 11.9 & 13.1 & 27.1 & 16.0 & 0.0 & 0.0 & 0.0 & 40.7 & & & & & & & & & & & & \\
\hline 12.2 & 13.3 & 27.4 & 16.3 & 0.0 & 0.0 & 0.0 & 41.2 & & & & & & & & & & & & \\
\hline 12.4 & 13.6 & 27.7 & 16.6 & 0.0 & 0.0 & 0.0 & 41.7 & & & & & & & & & & & & \\
\hline 12.6 & 13.8 & 28.1 & 16.8 & 0.0 & 0.0 & 0.0 & 42.2 & & & & & & & & & & & & \\
\hline 12.0 & 13.2 & 27.5 & 16.3 & 0.0 & 0.0 & 0.0 & 41.3 & & & & & & & & & & & & \\
\hline 7.7 & 8.6 & 19.3 & 11.2 & 0.0 & 0.0 & 0.0 & 29.2 & & & & & & & & & & & & \\
\hline
\end{tabular}


Table 3. Burn-up distribution over FA height

\section{T=281.2 EFPD}

\begin{tabular}{|c|c|c|c|c|c|c|c|c|c|c|c|c|c|c|c|c|c|c|c|}
\hline 1 & 2 & 3 & 4 & 5 & 6 & 7 & 8 & 9 & 10 & 11 & 12 & 13 & 14 & 15 & 16 & 17 & 18 & 19 & 20 \\
\hline 35.1 & 27.3 & 18.3 & 9.4 & 26.3 & 9.2 & 27.8 & 9.4 & 25.0 & 26.9 & 22.4 & 8.8 & 28.7 & 26.7 & 16.6 & 19.2 & 18.3 & 6.1 & 28.0 & 19.3 \\
\hline 49.8 & 39.8 & 26.9 & 13.9 & 38.8 & 14.2 & 42.0 & 14.0 & 37.4 & 38.6 & 34.3 & 14.0 & 42.2 & 38.8 & 24.9 & 29.0 & 27.2 & 10.0 & 40.9 & 29.0 \\
\hline 51.8 & 41.8 & 28.3 & 14.7 & 41.1 & 15.3 & 44.7 & 14.8 & 39.7 & 40.3 & 36.7 & 15.2 & 44.4 & 40.8 & 26.4 & 30.8 & 28.9 & 10.9 & 42.9 & 30.8 \\
\hline 52.2 & 42.3 & 28.6 & 14.9 & 41.7 & 15.7 & 45.4 & 15.0 & 40.3 & 40.7 & 37.3 & 15.6 & 44.9 & 41.2 & 26.8 & 31.3 & 29.3 & 11.3 & 43.4 & 31.4 \\
\hline 52.6 & 42.7 & 28.8 & 15.0 & 42.2 & 16.0 & 46.0 & 15.1 & 40.7 & 40.9 & 37.8 & 15.9 & 45.3 & 41.6 & 27.1 & 31.7 & 29.6 & 11.5 & 43.8 & 31.8 \\
\hline 52.9 & 43.1 & 29.0 & 15.1 & 42.7 & 16.3 & 46.5 & 15.3 & 41.2 & 41.2 & 38.3 & 16.3 & 45.8 & 41.9 & 27.4 & 32.2 & 30.0 & 11.7 & 44.3 & 32.2 \\
\hline 53.3 & 43.6 & 29.3 & 15.3 & 43.3 & 16.6 & 47.1 & 15.4 & 41.7 & 41.5 & 38.8 & 16.6 & 46.3 & 42.3 & 27.7 & 32.6 & 30.4 & 11.9 & 44.7 & 32.7 \\
\hline 53.8 & 44.0 & 29.5 & 15.4 & 43.7 & 16.8 & 47.6 & 15.6 & 42.2 & 41.8 & 39.3 & 16.9 & 46.7 & 42.7 & 28.1 & 33.1 & 30.7 & 12.1 & 45.2 & 33.1 \\
\hline 53.2 & 43.4 & 28.9 & 15.1 & 42.8 & 16.3 & 46.5 & 15.2 & 41.3 & 41.1 & 38.3 & 16.4 & 45.9 & 42.0 & 27.5 & 32.5 & 30.0 & 11.6 & 44.6 & 32.5 \\
\hline 39.3 & 31.3 & 20.6 & 10.7 & 30.6 & 11.2 & 32.6 & 10.7 & 29.2 & 30.0 & 26.6 & 11.0 & 32.9 & 30.4 & 19.3 & 22.9 & 21.3 & 7.5 & 32.3 & 23.0 \\
\hline 21 & 22 & 23 & 24 & 25 & 26 & 27 & 28 & & & & & & & & & & & & \\
\hline 16.2 & 13.4 & 25.4 & 18.2 & 6.9 & 8.8 & 6.2 & 28.3 & & & & & & & & & & & & \\
\hline 25.2 & 21.4 & 37.4 & 27.7 & 11.3 & 13.9 & 10.2 & 42.2 & & & & & & & & & & & & \\
\hline 27.2 & 23.3 & 39.4 & 29.7 & 12.5 & 15.2 & 11.3 & 44.7 & & & & & & & & & & & & \\
\hline 27.8 & 23.8 & 39.9 & 30.3 & 12.8 & 15.6 & 11.7 & 45.3 & & & & & & & & & & & & \\
\hline 28.2 & 24.2 & 40.3 & 30.8 & 13.1 & 15.9 & 11.9 & 45.8 & & & & & & & & & & & & \\
\hline 28.6 & 24.6 & 40.7 & 31.2 & 13.3 & 16.3 & 12.2 & 46.3 & & & & & & & & & & & & \\
\hline 29.1 & 25.0 & 41.1 & 31.7 & 13.6 & 16.6 & 12.4 & 46.8 & & & & & & & & & & & & \\
\hline 29.5 & 25.3 & 41.5 & 32.1 & 13.8 & 16.9 & 12.6 & 47.3 & & & & & & & & & & & & \\
\hline 28.8 & 24.5 & 40.9 & 31.3 & 13.2 & 16.3 & 12.0 & 46.4 & & & & & & & & & & & & \\
\hline 19.7 & 16.3 & 29.3 & 21.9 & 8.6 & 10.9 & 7.7 & 32.8 & & & & & & & & & & & & \\
\hline
\end{tabular}




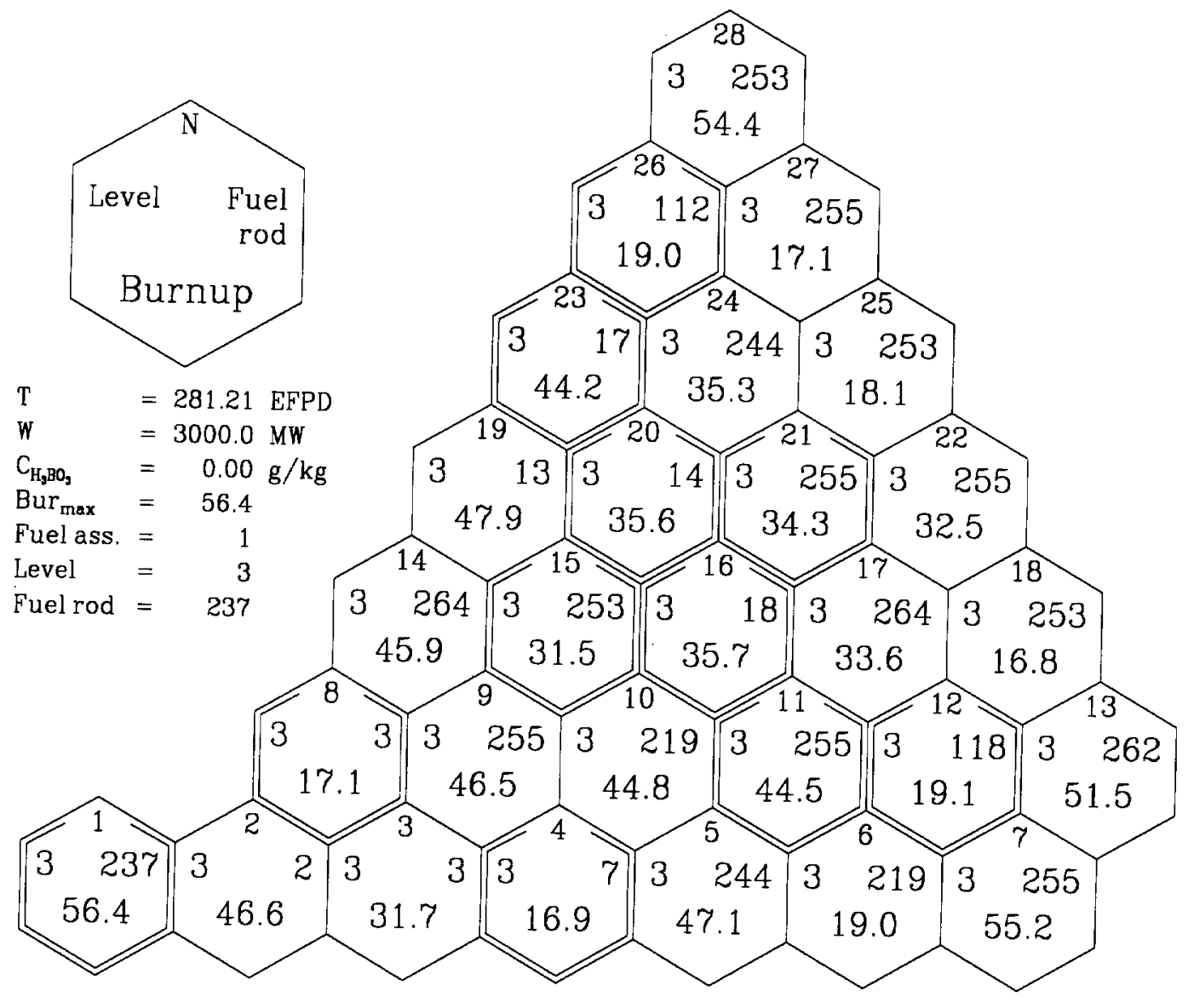

Fig. 5. Distribution of maximum burn-up of fuel pellets in FA, MWd/kg 


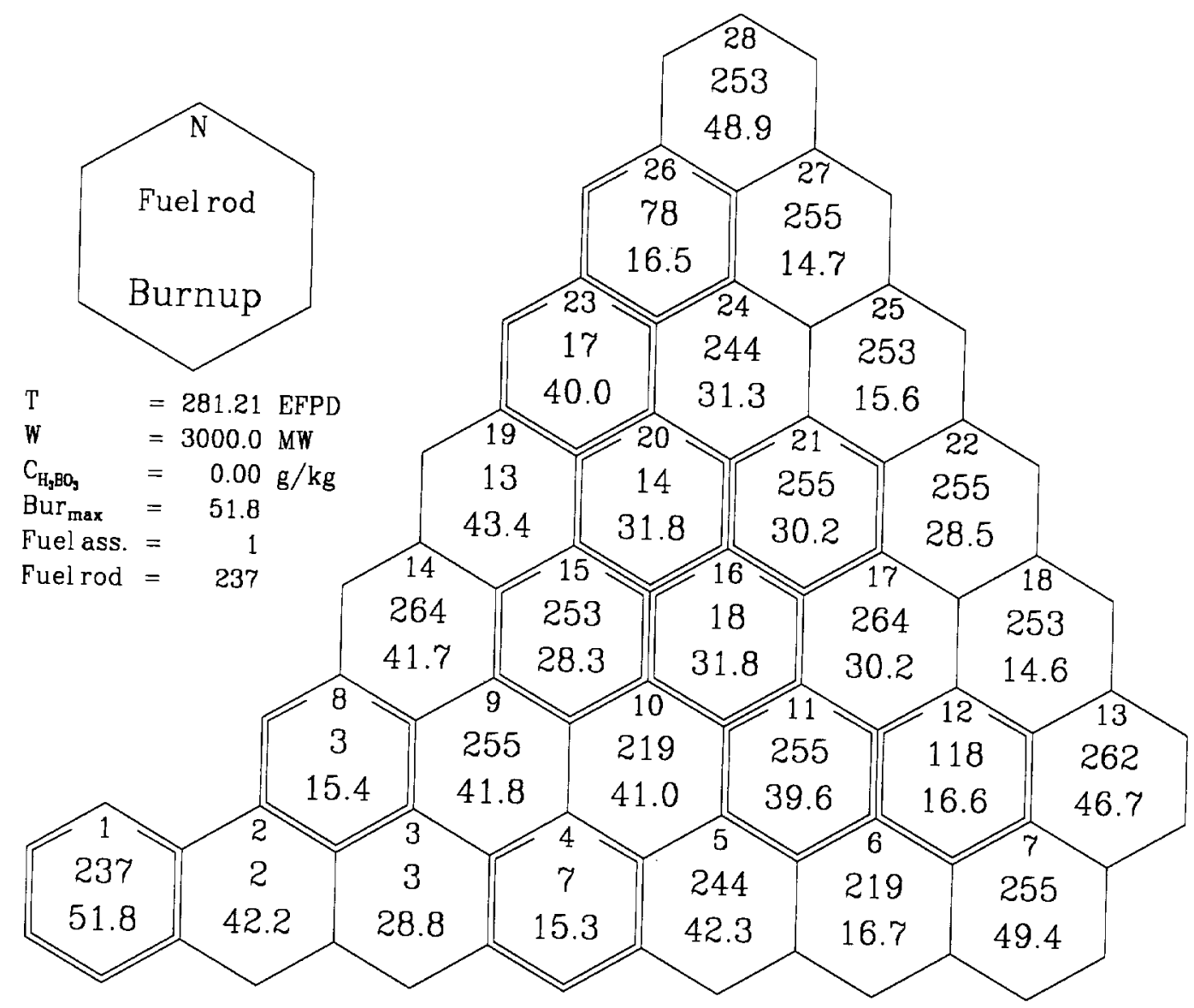

Fig. 6. Distribution of maximum burn-up of fuel rods in FA, MWd/kg 
Table 4. Core Criticality (Scram Margin) in different states in the process of Scram actuation

\begin{tabular}{|c|c|c|c|c|c|c|c|c|c|}
\hline \multicolumn{6}{|c|}{ State parameters } & \multicolumn{4}{|c|}{ Reactivity, \% } \\
\hline \multirow{2}{*}{ 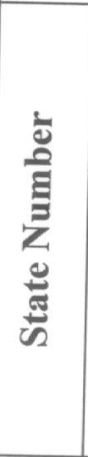 } & \multirow{2}{*}{ 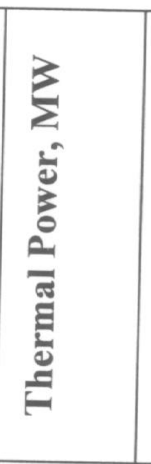 } & \multirow{2}{*}{ 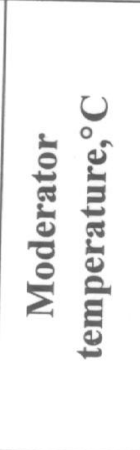 } & \multirow{2}{*}{ 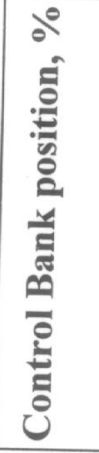 } & \multirow{2}{*}{ 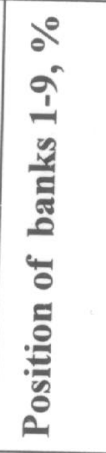 } & \multirow{2}{*}{ 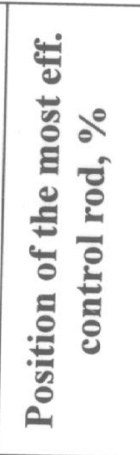 } & \multicolumn{2}{|c|}{ 1/3 MOX FAs } & \multicolumn{2}{|c|}{$\begin{array}{c}\text { UOX } \\
\text { B-320 }\end{array}$} \\
\hline & & & & & & ర్ల & 己ِ & Øֶ & రૃ \\
\hline \multirow[t]{2}{*}{1} & 3000 & Nom. & 100 & 100 & 100 & +0.2 & +0.3 & +0.3 & +0.3 \\
\hline & \multicolumn{9}{|c|}{ Regulation margin of reactivity } \\
\hline \multirow[t]{2}{*}{2} & 3000 & Nom. & 70 & 100 & 100 & +0.0 & +0.0 & +0.0 & +0.0 \\
\hline & \multicolumn{9}{|c|}{ Scram actuation without sticking of the most effective CR } \\
\hline \multirow[t]{2}{*}{3} & 3000 & Nom. & $\mathbf{0}$ & $\mathbf{0}$ & $\mathbf{0}$ & -8.2 & -8.1 & -8.2 & -8.2 \\
\hline & \multicolumn{9}{|c|}{ Scram actuation with sticking of the most effective CR } \\
\hline \multirow[t]{2}{*}{4} & 3000 & Nom. & 0 & $\mathbf{0}$ & 100 & -7.6 & -7.3 & -7.4 & -7.1 \\
\hline & \multicolumn{9}{|c|}{ Uncertainty of (RO) AP calculation $(10 \%$ of p. 4$)$} \\
\hline \multirow[t]{2}{*}{5} & 3000 & Nom. & 0 & $\mathbf{0}$ & 100 & -6.8 & -6.5 & -6.6 & -6.4 \\
\hline & \multicolumn{9}{|c|}{ Vapor effect $(\Delta p=100 \mathrm{pcm})$} \\
\hline \multirow[t]{2}{*}{6} & 3000 & Nom. & $\mathbf{0}$ & 0 & 100 & -6.7 & -6.4 & -6.5 & -6.3 \\
\hline & \multicolumn{9}{|c|}{ Doppler effect with $5 \%$ uncertainty } \\
\hline \multirow[t]{2}{*}{7} & 0 & Nom. & $\mathbf{0}$ & $\mathbf{0}$ & 100 & -5.5 & -5.2 & -5.5 & -5.2 \\
\hline & \multicolumn{9}{|c|}{ Temperature effect with $5 \%$ uncertainty } \\
\hline \multirow[t]{2}{*}{8} & 0 & 287 & 0 & $\mathbf{0}$ & 100 & -4.8 & -3.7 & -4.7 & -3.5 \\
\hline & \multicolumn{9}{|c|}{ Temperature effect with $5 \%$ uncertainty } \\
\hline \multirow[t]{2}{*}{9} & 0 & 280 & 0 & 0 & 100 & -4.5 & -3.2 & -4.5 & -3.1 \\
\hline & \multicolumn{9}{|c|}{ Temperature effect with $5 \%$ uncertainty } \\
\hline \multirow[t]{2}{*}{10} & 0 & 200 & 0 & $\mathbf{0}$ & 100 & -2.7 & +0.4 & -2.8 & +0.4 \\
\hline & \multicolumn{9}{|c|}{ Temperature effect with $5 \%$ uncertainty } \\
\hline \multirow[t]{2}{*}{11} & 0 & 120 & 0 & 0 & 100 & -1.8 & +2.4 & -2.0 & +2.2 \\
\hline & Tempe & rature eff & et wit & & & & & & \\
\hline 12 & 0 & 27 & 0 & 0 & 100 & -1.1 & +4.0 & -1.2 & +3.8 \\
\hline
\end{tabular}

Equilibrium $100 \%$ power poisoning by Xenon and Samarium is used in all states.

Boron concentration in all states is equal to critical boron concentration in state 2. 
Fig. 7. Core Reactivity versus Moderator Temperature.

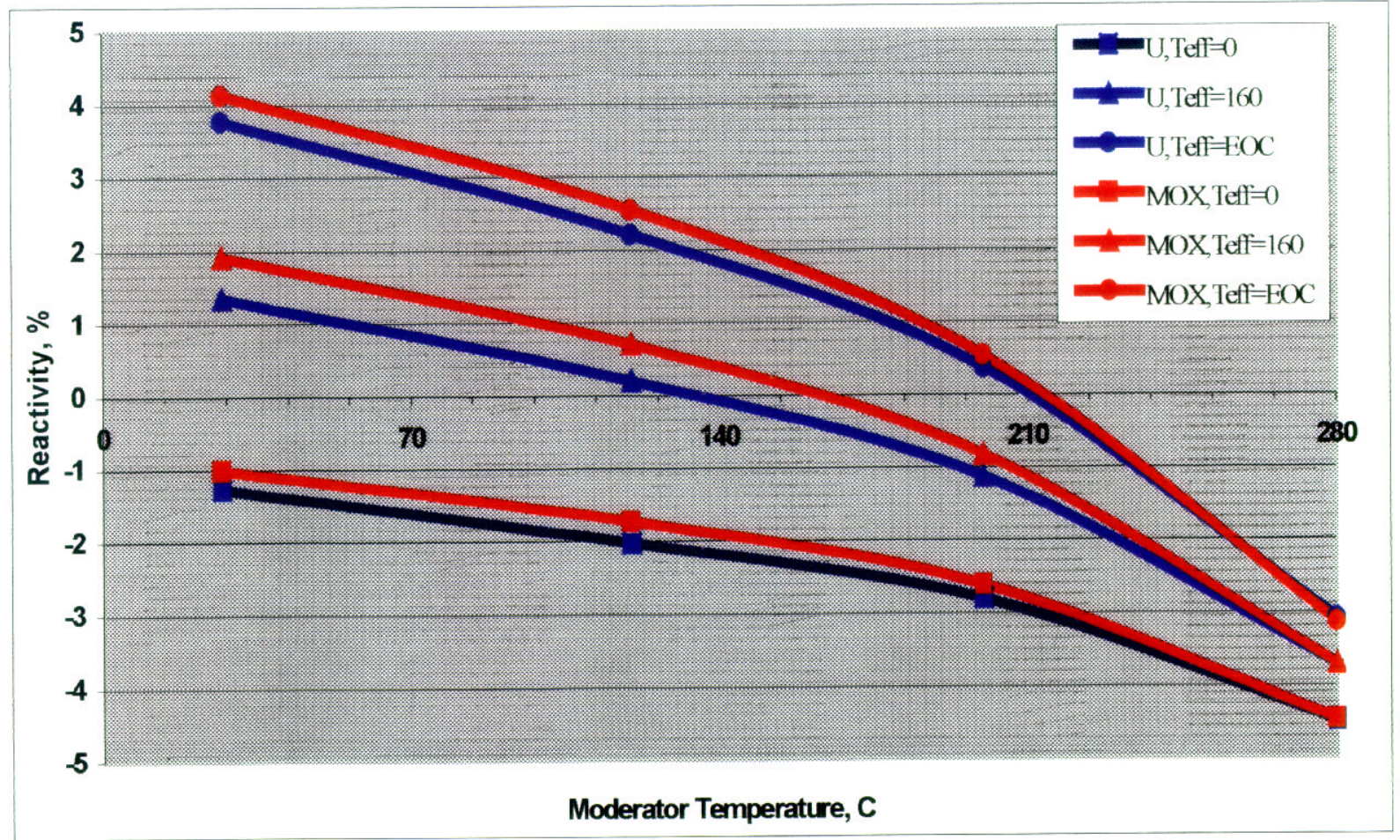

Fig. 8. Core Reactivity versus Moderator Temperature (Different type of control rods)

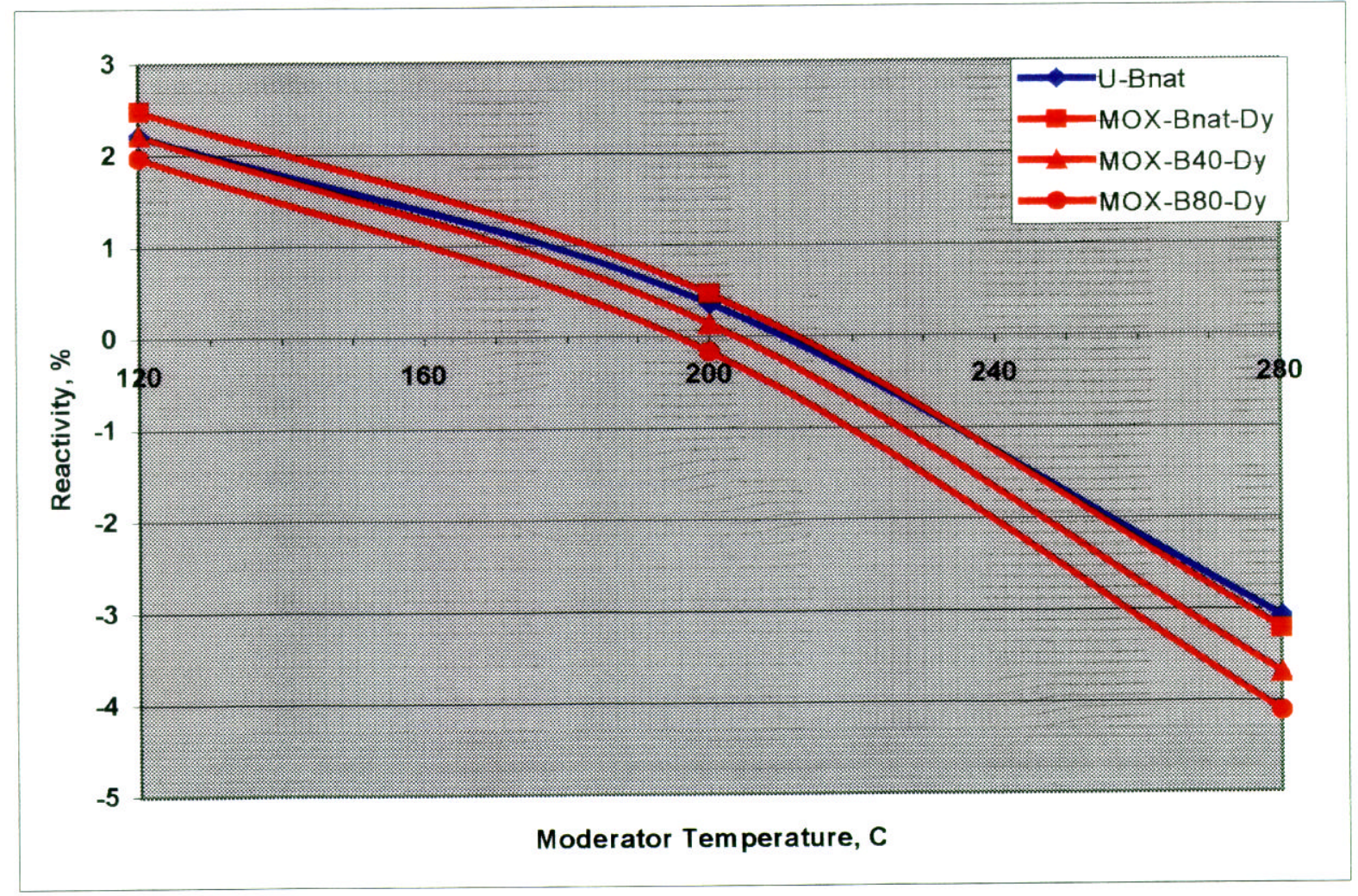




\section{Conclusion}

1. The report presents equilibrium fuel cycle in VVER-1000 core with $1 / 3$ MOX assemblies of weapons-grade plutonium. The main features of proposed cycles are the following:

- Equilibrium fuel cycle is elaborated on the base of advanced assembly with Zirconium construction elements. The principle of direct replacement of UOX fuel by MOX one, without noticeable assembly and core design modifications, has been used.

- MOX fuel fraction in core is about $1 / 3$. The only type of MOX assembly with average fissile plutonium content of $3.43 \%$ and $\mathrm{U}^{235}$ $0.2 \%$ is used. MOX assembly is graded in plane by three types of fuel rods with different plutonium content for power inter-assembly flattening. Maximum content of fissile plutonium isotopes is of $3.6 \%$, minimum one $-2.4 \%$.

- In the equilibrium fuel cycle 11 UOX assemblies burn during 3 cycles, 19 Uranium assemblies - four cycles, $18 \mathrm{MOX}$ assemblies (all in core center) - three cycles.

- BPRs in the form of uranium-gadolinium fuel elements are located in a part of UOX assemblies and in all MOX assemblies in order to suppress an excess of core reactivity and to flatten additionally a power distribution. MOX assemblies contain 18 uranium-gadolinium BPRs with $\mathrm{Gd}_{2} \mathrm{O}_{3}$ fraction of $4 \%$ wt. and $\mathrm{U}^{235}$ enrichment of $3.6 \%$.

- Combined absorber rods with the upper part of $\mathrm{B}_{4} \mathrm{C}$ (natural $\mathrm{B}_{10}$ content) and the lower part of $\mathrm{Dy}_{2} \mathrm{O}_{3}{ }^{*} \mathrm{TiO}_{2}$ are used in the mechanical part of emergency-regulation reactor system.

- A part of irradiated assemblies is placed in the core periphery in the nearest to reactor vessel locations in order to lower vessel neutron fluence and to increase emergency system effectiveness. Fresh MOX assemblies are not placed in the core periphery as they are characterized by approximately $20 \%$ more fission neutrons than fresh Uranium assemblies.

2. The calculational results for fuel cycle with $1 / 3$ MOX core are accumulated in Table C.1. For comparison the characteristics of equilibrium uranium fuel cycle (Project B-320) are also presented in the Table. Analysis of the results leads to the following conclusions: 
- Annual weapons-grade plutonium disposition is about of $270 \mathrm{~kg}$ in both options. In discharged MOX fuel the average fissile plutonium content in plutonium does not exceed $65 \%$ i.e. it is lower than in discharged uranium fuel. So the task of weapons-grade plutonium transformation into the "standard of irradiated fuel" is performed with a significant margin.

- For fuel cycle length of about 7000 EFPH and MOX assemblies irradiation during 3 cycles, average burn-up of discharged MOX assemblies is $38.8 \mathrm{MW}^{*} \mathrm{~d} / \mathrm{kgHM}$. It confirms a sufficient extraction of weapons-grade plutonium power potential. Maximum average burn-up in MOX assembly attains $39.3 \mathrm{MW}^{*} \mathrm{~d} / \mathrm{kgHM}$. Average and maximum burn-ups in UOX assemblies are higher (maximum burn-up is in the forth-year assembly located in the central core position) but do not exceed $50 \mathrm{MW}^{*} \mathrm{~d} / \mathrm{kgHM}$.

- Mox core reactivity in the cold state with shut-down boron acid concentration (16000 ppm) is greater than in UOX core but does not exceed $-7000 \mathrm{pcm}$. It should be noted that this calculated value is not conservative because calculation errors and eventual operator errors during assemblies reloading are not taken into account. Necessary analysis must be performed in future.

- Reactivity effects and coefficients on coolant and fuel temperature are negative and on coolant density is positive for all core critical states. Absolute values of above-mentioned coefficients in MOX fuelled core is higher than in UOX one. So the MOX fuelled reactor possesses more significant feed back allowing compensation of fast reactivity variation and limiting power increase.

- Regulating CR bank in VVER-1000 MOX fuelled core is transferred to the position № 15 (in 60 degr. symmetry) from the position № 4 (in the Project B-320). Such positioning ensures a necessary effectiveness of Regulating CR bank, facilitates core loading composing with low peaking power factors and lowers power distribution perturbations while the bank moving. Effectiveness of Regulating CR bank meets the safety requirements on both negative and positive reactivity introduction speed.

- Effectiveness criteria of the mechanical part of emergency-regulation reactor system (effectiveness of emergency system and core subcriticality after emergency system actuation) are very close both in MOX and UOX cores. As it is shown in the Document, it could be possible to use in AR a boron with $60-80 \%$ enrichment in $\mathrm{B}_{10}$, in order to create some margin on emergency system effectiveness in MOX fuel cycles. 
- Power peaking factors for MOX fuel cycles meet with a small margin the limits established for UOX FAs in VVER-1000 Project. But MOX fuel thermo-physical properties are a little worse than the UOX ones. Besides, according to performed estimation studies, the engineering margin coefficients and calculational errors are greater for MOX fuel. So the applicability of the elaborated MOX fuel cycles should be confirmed by thermo-hydraulic calculations. It should be noted that the mentioned MOX fuel particularity and also the necessity of irradiated MOX fuel positioning in a core periphery demand an improvement of representativity of in-core detecting system in MOX fuelled VVER-1000

- Effective fraction of delayed neutrons and lifetime of prompt neutrons are lower of $10 \%$ in MOX fuel cycle in comparison with UOX ones. So more attention should pay to safety analysis in reactivity accidents calculations.

- MOX core in comparison with UOX core is more stable in respect to xenon oscillations of integral power and spatial power distribution, that provides more reliable operation of reactor.

3. Presented results leads to the conclusion that neutronics characteristics defining reactor safety are close for MOX fuel cycle and Project UOX fuel cycle. 
Table C.1. Characteristics of UOX and MOX (1/3) Equilibrium Fuel Cycle

\begin{tabular}{|c|c|c|c|}
\hline \multirow[t]{2}{*}{ Name of characteristic } & \multirow[t]{2}{*}{ Clarification } & \multicolumn{2}{|c|}{ Type of Cycle } \\
\hline & & $\begin{array}{r}\text { UOX } \\
\text { B-320 } \\
\end{array}$ & 1/3 MOX \\
\hline Number of fresh FA loaded during refuelling, pcs & $\begin{array}{l}\mathrm{U}^{235}-4.23 \% \\
\mathrm{U}^{235}-4.40 \% \\
\mathrm{U}^{235}-4.08 \%(4.2 / 3.7 \%) \\
\mathrm{U}^{235}-3.70 \% \\
\mathrm{U}^{235}-0.20 \%, \mathrm{Pu}^{239+241}-3.43 \%\end{array}$ & $\begin{array}{l}30 \\
24 \\
- \\
- \\
- \\
\end{array}$ & $\begin{array}{c}- \\
- \\
30 \\
- \\
18 \\
\end{array}$ \\
\hline Weight of fuel rod $\mathrm{UO}_{2} /\left(\mathrm{UO}_{2}+\mathrm{PuO}_{2}\right), \mathrm{kg}$ & & 1.465 & $1.575 / 1.600$ \\
\hline $\begin{array}{l}\text { Number of burnable poisons rods } \\
\text { in fresh FA, pcs }\end{array}$ & $\begin{array}{l}\text { Boron BPR (in UOX FA) } \\
\text { U-Gd Fuel (in UOX FA) } \\
\text { U-Gd Fuel (in MOX FA) } \\
\end{array}$ & $\begin{array}{c}18 \\
- \\
- \\
\end{array}$ & $\begin{array}{c}- \\
6 \\
18 \\
\end{array}$ \\
\hline $\begin{array}{l}\text { Material of tubes and grids } \\
\text { Part of MOX fuel, } \%\end{array}$ & & Fe & $\mathbf{Z r}$ \\
\hline Part of MOX fuel, $\%$ & & - & 33 \\
\hline Annular plutonium utilization, $\mathrm{kg}$ & & - & 270 \\
\hline Weight of discharged plutonium, $\mathrm{kg}$ & $\begin{array}{l}\text { Total } \\
\text { UOX FAs } \\
\text { MOX FAs } \\
\end{array}$ & $\begin{array}{c}238 \\
238 \\
- \\
\end{array}$ & $\begin{array}{l}337 \\
147 \\
190 \\
\end{array}$ \\
\hline Fuel burn-up, MWd/ kg & $\begin{array}{l}\text { Average, UOX FAs } \\
\text { Average, MOX FAs } \\
\text { MAX, UOX FAs } \\
\text { MAX, MOX FAs } \\
\text { MAX, UOX Fuel Rods } \\
\text { MAX, MOX Fuel Rods }\end{array}$ & $\begin{array}{c}41.2 \\
- \\
48.1^{1)} \\
- \\
54.0^{1)} \\
-\end{array}$ & $\begin{array}{c}42.0 \\
38.8 \\
49.4^{1)} \\
39.3^{1)} \\
52.0^{1)} \\
42.3 \\
\end{array}$ \\
\hline $\begin{array}{l}\text { Content of Plutonium Isotopes } \\
\text { in Fresh MOX Fuel, \% }\end{array}$ & $\begin{array}{l}\mathrm{Pu}^{239} \\
\mathrm{Pu}^{240} \\
\mathrm{Pu}^{241}\end{array}$ & $\begin{array}{l}- \\
- \\
-\end{array}$ & $\begin{array}{c}93 \\
6 \\
1 \\
\end{array}$ \\
\hline
\end{tabular}


Table C.1. Characteristics of UOX and MOX (1/3) Equilibrium Fuel Cycles ( continuation 1 )

\begin{tabular}{|c|c|c|c|c|}
\hline $\begin{array}{l}\text { Content of Plutonium Isotopes } \\
\text { in Spent UOX Fuel, } \%\end{array}$ & $\begin{array}{l}\mathrm{Pu}^{239} \\
\mathrm{Pu}^{240} \\
\mathrm{Pu}^{241} \\
\mathrm{Pu}^{242}\end{array}$ & & $\begin{array}{l}56.4 \\
23.4 \\
13.3 \\
5.2\end{array}$ & $\begin{array}{c}55.2 \\
23.9 \\
13.4 \\
5.7\end{array}$ \\
\hline $\begin{array}{l}\text { Content of Plutonium Isotopes } \\
\text { in Spent MOX Fuel, } \%\end{array}$ & $\begin{array}{l}\mathrm{Pu}^{239} \\
\mathrm{Pu}^{240} \\
\mathrm{Pu}^{241} \\
\mathrm{Pu}^{242} \\
\end{array}$ & & $\begin{array}{l}- \\
- \\
- \\
-\end{array}$ & $\begin{array}{c}46.5 \\
31.5 \\
15.6 \\
5.9\end{array}$ \\
\hline Cycle length, EFPD & CRs out & & 298 & 282 \\
\hline Critical boron acid concentration in coolant, ppm & Full Power & $\mathrm{BOC}$ & 6720 & 6930 \\
\hline Reactivity at $16 \mathrm{~g} / \mathrm{kg} \mathrm{H}_{3} \mathrm{BO}_{3}$ & Cold state, CRs out, & $\mathrm{BOC}$ & -10.6 & -7.4 \\
\hline Boron acid coefficient of reactivity, $\% /(\mathrm{g} / \mathrm{kg})$ & $\begin{array}{l}\text { Full power } \\
\text { EOC }\end{array}$ & BOC & $\begin{array}{l}1.4 \\
1.6 \\
\end{array}$ & $\begin{array}{l}1.2 \\
1.5 \\
\end{array}$ \\
\hline Moderator temperature coefficient of reactivity, $\mathrm{pcm} /{ }^{\circ} \mathrm{C}$ & $\begin{array}{l}\text { MCL, CRs out, } \\
\text { Full power }\end{array}$ & $\begin{array}{l}\mathrm{BOC} \\
\mathrm{BOC} \\
\mathrm{EOC} \\
\end{array}$ & $\begin{array}{l}0.0 \\
-23 \\
-61\end{array}$ & $\begin{array}{l}1.5 \\
-5 \\
-30 \\
-66 \\
\end{array}$ \\
\hline Fuel temperature coefficient of reactivity, $\mathrm{pcm} /{ }^{\circ} \mathrm{C}$ & $\begin{array}{l}\text { MCL, CRs out, } \\
\text { Full power }\end{array}$ & $\begin{array}{l}\mathrm{BOC} \\
\mathrm{BOC} \\
\mathrm{EOC}\end{array}$ & $\begin{array}{l}-2.8 \\
-2.5 \\
-2.7 \\
\end{array}$ & $\begin{array}{l}-3.2 \\
-2.6 \\
-2.7 \\
\end{array}$ \\
\hline $\begin{array}{l}\text { Moderator density coefficient of reactivity, } \\
1 /\left(\mathrm{g} / \mathrm{cm}^{3}\right) * 10^{-2}\end{array}$ & $\begin{array}{l}\text { MCL, CRs out, } \\
\text { Full power }\end{array}$ & $\begin{array}{l}\text { BOC } \\
\text { BOC } \\
\text { EOC } \\
\end{array}$ & $\begin{array}{c}2.2 \\
10.9 \\
28.8 \\
\end{array}$ & $\begin{array}{c}5.4 \\
14.8 \\
33.1 \\
\end{array}$ \\
\hline Regulation bank worth, \% & Full power & $\begin{array}{l}\text { BOC } \\
\text { EOC }\end{array}$ & $\begin{array}{l}0.75 \\
0.70\end{array}$ & $\begin{array}{l}0.80 \\
0.79\end{array}$ \\
\hline Control and protection system efficiency, $\%$ & $\begin{array}{l}\text { Full power, } \text { MECR }^{2)} \text { out, } \\
\text { EOC } \\
\text { MCL, MECR out, } \\
\text { EOC } \\
\end{array}$ & BOC & $\begin{array}{l}7.4 \\
7.1 \\
6.6 \\
6.3 \\
\end{array}$ & $\begin{array}{l}7.6 \\
7.3 \\
6.7 \\
6.7 \\
\end{array}$ \\
\hline
\end{tabular}


Table C.1. Characteristics of UOX and MOX (1/3) Equilibrium Fuel Cycles ( continuation 2)

\begin{tabular}{|c|c|c|c|c|}
\hline Repeat criticality temperature, ${ }^{\circ} \mathrm{C}$ & $\begin{array}{l}\text { Xe eq, MECR out } \\
\text { Direct calculation } \\
\text { Conservative estimation } \\
\end{array}$ & $\begin{array}{l}\text { EOC } \\
\text { EOC } \\
\end{array}$ & $\begin{array}{l}157 \\
210 \\
\end{array}$ & $\begin{array}{l}161 \\
210 \\
\end{array}$ \\
\hline Shut-down margin, $\%$ & $\begin{array}{l}280^{\circ} \mathrm{C}, \mathrm{Xe} \text { eq, MECR out, } \\
\text { Direct calculation } \\
\text { Conservative estimation } \\
\end{array}$ & $\begin{array}{l}\text { EOC } \\
\text { EOC } \\
\end{array}$ & $\begin{array}{l}4.3 \\
3.1 \\
\end{array}$ & $\begin{array}{r}4.5 \\
3.2 \\
\end{array}$ \\
\hline Maximum normalised power of FA over cycle & $\begin{array}{l}\text { UOX FA } \\
\text { MOXFA } \\
\end{array}$ & & $\begin{array}{c}1.29 \\
- \\
\end{array}$ & $\begin{array}{l}1.31 \\
1.27 \\
\end{array}$ \\
\hline Maximum normalised power of fuel pin over cycle & \begin{tabular}{|l|} 
UOX fuel rods \\
MOX fuel rods \\
\end{tabular} & & $\begin{array}{c}1.46 \\
- \\
\end{array}$ & $\begin{array}{l}1.45 \\
1.45 \\
\end{array}$ \\
\hline Maximum fuel pin linear power over cycle, W/cm & \begin{tabular}{|l|} 
UOX fuel rods \\
MOX fuel rods \\
\end{tabular} & & $\begin{array}{c}271 \\
- \\
\end{array}$ & $\begin{array}{l}\mathbf{2 8 7} \\
\mathbf{2 8 8} \\
\end{array}$ \\
\hline Effective Fraction of Delayed Neutrons, $\%$ & Full power, & $\begin{array}{r}\mathrm{BOC} \\
\mathrm{EOC} \\
\end{array}$ & $\begin{array}{l}0.64 \\
0.56 \\
\end{array}$ & $\begin{array}{l}0.53 \\
0.51 \\
\end{array}$ \\
\hline $\begin{array}{l}\text { Lifetime of prompt neutrons, ceK*10 } \\
\text { I) Central Fuel Assembly }\end{array}$ & Full power, & $\begin{array}{r}\text { BOC } \\
\text { EOC }\end{array}$ & \begin{tabular}{|l|}
2.1 \\
2.4 \\
\end{tabular} & $\begin{array}{l}1.8 \\
2.1 \\
\end{array}$ \\
\hline
\end{tabular}

${ }^{2)}$ MECR - Maximum efficient Control Rod 


\section{References}

1. Physics and Fuel Performance of Reactor-Based Plutonium Disposition. AEN/NEA, Workshop Proceedings, Paris, France, 28-30 September 1998.

2. Novikov A.N. et al. Use of MOX ( R-U and W-U ) Fuel in VVER-1000 ( NeutronPhysical aspects of possibilities). Proc. of Meeting of Workshop on Managing The Plutonium Surplus: Application and Options. London, 24-25 January 1994.

3. Use of Weapon-Grade Plutonium from Dismantled Nuclear Weapons for the Peaceful Objective of Electric Power Generation. AIDA/MOX1 (1993-1996). Final Report. 1997.

4. Вознесенский В.А., Семенов В.В. и др. Эксплуатационные режимы АЭС с ВВЭР-1000. М., Энергоатомиздат, 1992

5. Novikov A. Prospects for improvement of VVER fuel management and MOX Utilization. Safety Issues Associated with Plutonium Improvement in the Nuclear Fuel Cycle, p.111.Kluwer Academic Publishers, 1999.

6. Sidorenko V. et al. Spectral Code TBC-M for Calculation of Characteristics of Cells, Super-cells and Fuel Assemblies of VVER-Type Reactors. 5-th Symposium of the AER, Dobogoko, Hungary, October 15-20, 1995.

7. Novikov A. et al. Problems of VVER In-core Fuel Management, IAEA-TECDOC567, In-core Fuel Management Practices, IAEA, Vienna, 1990

8. Bychkov S. et al. Benchmarks for neutronics codes. Comparison of results obtained with various codes. Joint US/Russian Project. RRC KI, 1999.

9. Pavlovichev A. Validation of Neutronic Computer Codes Assosiatd with MOX Fuel Usage in VVER-1000 Reactor. Third Topical Meeting on DOE Spent Nuclear Fuel and Fissile Materials Management. Vol. 2, p. 606. Charleston, SC, 1998. 


\section{Review of Mission MOX Fuel Physics Design-Preliminary Equilibrium MOX Assembly Design and Expected Operating Power for Existing Balakovo Fuel Management Scheme by D. T. Ingersoll and R. T. Santoro, Oak Ridge National Laboratory}

\section{General Comments}

The work appears to be technically correct. The results presented in the figures and tables are consistent. The main criticism of the report is that it is not a "stand-alone" document. For example, after the introduction, the results are presented with no clear indication of how the data were obtained. The author does not explain the sequence in which the calculations were carried out although he did mention the use of several codes, including attempts to benchmark them.

It is suggested that future documents either provide a complete set of references or follow a more systematic approach such as the following:

Introduction

Methods of Calculation

Include descriptions of the codes and data and details on the reactor models.

Discussion of Results

Include discussion of uncertainties.

Conclusions

\section{Corrections to Acronyms for Consistency}

Change the following terms:

- "Russian authority for nuclear safety" to "Russian Authority for Nuclear Safety"

- "Mixed Oxide (uranium-plutonium fuel)" to "Mixed Oxide (Uranium-Plutonium Fuel)"

- "Zirconium fuel for cladding" to "Zirconium Fuel for Cladding"

- "Russian water-water reactor" to "Russian Water-Water Reactor"

\section{Text Comments}

1. Page 5, paragraph 1, line 1: Add "," after "handling."

2. Page 5, paragraph 1, line 3: Change "power value" to "energy content."

3. Page 5, paragraph 2, suggested wording for first sentence: "Options for burning weapons grade plutonium in VVER-, BN-, HTGR-type reactors are being developed in Russia."

4. Page 5, paragraph 2, suggested wording for second sentence: "Experience in the use of mixed uranium-plutonium fuel gained in the West along with preliminary results obtained in Russia [1-3] show that ....."

5. Page 5, paragraph 3, suggested wording: "Russia has seven VVER-1000 in operation with a total capacity of $11 \mathrm{GWE}$. Eleven of these reactors are in operation in the Ukraine and two are running in Bulgaria. It is planned to put two additional VVER-1000 units into operation in Russia and at leas two into operation in the Ukraine before the tear 2003."

6. Page 5, paragraph 4, suggested wording: "The core designs of all VVERs are essentially the same. The main differences are in the number of control rods."

7. Page 5, paragraph 5, suggested wording: "Therefore, it is used as the reference cycle....."

8. Page 5, paragraph 5, suggested wording: "Part 2 describes the main characteristics of the ....."

9. Page 5, paragraph 6, suggested wording: "At present, extensive efforts are underway in Russia on the VVER-1000 [5] advanced fuel cycle."

10. Page 5, paragraph 6, suggested wording: “.....control rods consisting of two parts: the upper region comprised of $\mathrm{B}_{4} \mathrm{C}$ and the lower region comprised of $\mathrm{Dy}_{2} \mathrm{O}_{3} \cdot \mathrm{TiO}_{2}$." 
11. Page 6, paragraph 1, line 1: Change "By present" to "At present."

12. Page 6, paragraph 1, line 1: Change "has" to "have."

13. Page 6, paragraph 1, suggested wording: "In Russia, the basic parameters for large-scale implementation of advanced fuel cycles improved FAs and uranium-gadolinium fuel have been established.

- pilot operation of FAs with UGF is being conducted at the Balakovo NPP.

$-$

- in many VVER1000 reactors, low leakage loading patterns have been successfully used."

14. Page 6, paragraph 3, suggested wording:

"In Russia, calculational studies

Emphasis is placed on the most simple ......."

15. Page 6, paragraph 4, suggested wording:

- Investigations by Russian and Western specialists have shown $[1,2]$ that the ....

$-$

$-$

- ... between MOX and UOX FAs making it necessary to use ....."

16. Page 6, paragraph 4, line 2: Change "civil" to "civilian."

17. Page 7 , paragraph 1 , suggested wording:

"Code BIPR-7A .........samarium transients, etc.,

Code PERMAK-A ......power and burn-up distributions"

18. Page 7, paragraph 2, suggested wording:

"......calculated errors in MOX fuelled core is a difficult task.

Therefore, ..........current stage of code verification.

Some years ago, ............were engaged in code verification."

19. Page 8, paragraph 1, suggested wording: “.....5\% and $4 \%$ to lower the neutron multiplication in fresh UOX and MOX FAs."

20. Page 8, paragraph 5, suggested wording: “.....calculated errors associated with emergency systems ......."

21. Page 8, paragraph 6, suggested wording: “......Boron-10 content in the upper part of the combined absorber was varied from natural boron to $80 \mathrm{wt} \%$ enriched boron."

22. Table 1. Use the notation wt \% throughout.

23. Table C.1 (continuation 2), last row should read: "Lifetime of prompt neutrons, $\sec ^{*} 10^{-5}$ ",

24. Page 13, Fig. 4: Should define symbols on graph axes (Kq, Kv, etc.).

25. Page 14, Table 2: Should specify core height values corresponding to rows.

26. Page 20, first set of conclusions, suggested wording:

First bullet: "The equilibrium fuel cycle is reviewed on the basis of ........."

"The principle of direct replacement of UOX fuel with MOX ....."

Third bullet: "In the equilibrium fuel cycle, eleven UOX assemblies burn-up during three cycles, nineteen $\mathrm{U}$ assemblies burn-up during four cycles, and eighteen MOX assemblies (all in the core center) burn-up in three cycles."

Fourth bullet: "...... are located in parts of the UOX assemblies .............and to additionally flatten the power distribution."

Fifth bullet: “.......upper part comprised of $\mathrm{B}_{4} \mathrm{C}$ and the lower part comprised of $\mathrm{Dy}_{2} \mathrm{O}_{3} \cdot \mathrm{TiO}_{2}$."

Sixth bullet: "Some of the irradiated samples are placed in the core periphery close to the reactor vessel to lower the neutron fluence in the vessel."

27. Page 18, Table 4: Need to define " $(\mathrm{RO})_{\mathrm{AP}}$."

28. Page 20, second set of conclusions, suggested wording: “.....1/3 MOX core is summarized in Table C.1. For comparison, ......." 
29. Page 21, third bullet: Change "Mox" to "MOX."

30. Page 21, suggested wording for first bullet: ".....deposition is about $270 \mathrm{~kg}$ in both options."

31. Page 22, suggested wording for second bullet: "prompt neutrons are $10 \%$ lower in MOX ..."

32. Page 23, Table C.1: Change "Annular plutonium" to "Annual plutonium." 
ORNL/SUB/00-85B99398V-11

\section{INTERNAL DISTRIBUTION}

$\begin{aligned} \text { 1-4. } & \text { B. B. Bevard } \\ 5 . & \text { R. J. Belles } \\ 6 . & \text { J. J. Carbajo } \\ \text { 7. } & \text { M. D. DeHart } \\ \text { 8. } & \text { F. C. Difilippo } \\ 9 . & \text { M. E. Dunn } \\ \text { 10. } & \text { R. J. Ellis } \\ \text { 11. } & \text { J. C. Gehin } \\ \text { 12. } & \text { S. R. Greene } \\ \text { 13. } & \text { S. Goluoglu } \\ \text { 14. } & \text { R. F. Holdaway } \\ \text { 15. } & \text { D. Hollenbach }\end{aligned}$

16. C. M. Hopper

17. D. T. Ingersoll

18. M. A. Kuliasha

19. S. B. Ludwig

20. G. E. Michaels

21. L. J. Ott

22-23. R. T. Primm III

24. C. E. Sanders

25. C. C. Southmayd

26. D. L. Williams, Jr.

27. Central Research Library

28. ORNL Laboratory Records-RC

\section{EXTERNAL DISTRIBUTION}

29. M. L. Adams, Department of Nuclear Engineering, Texas A\&M University, Zachry 129, 3133 TAMU, College Station, TX 77843

30. H. Akkurt, 2919 Cooley Building, 2355 Bonisteel Boulevard, Ann Arbor, MI 48109-2104

31. D. Alberstein, Office of Fissile Materials Disposition, U.S. Department of Energy, NN-63, 1000 Independence Avenue SW, Washington, DC 20585

32. J. B. Briggs, Idaho National Environmental and Engineering Laboratory, P.O. Box 16253855, Idaho Falls, ID 83415-3855

33. J. Baker, Office of Fissile Materials Disposition, U.S. Department of Energy, NN-63, 1000 Independence Avenue SW, Washington, DC 20585

34. K. Chidester, Los Alamos National Laboratory, P.O. Box 1663, MS-E502, Los Alamos, NM 87545

35. W. Danker, U.S. Department of Energy, NN-62, 1000 Independence Avenue SW, Washington, DC 20585

36. T. Gould, Lawrence Livermore National Laboratory, P.O. Box 808, MS-L186, Livermore, CA 94551

37. L. Jardine, Lawrence Livermore National Laboratory, P.O. Box 808, MS-L166, Livermore, CA 94551

38. Dr. Alexander Kalashnikov, Institute of Physics and Power Engineering, 1 Bondarenko Square, Obninsk, Kaluga Region, Russia 249020

39-43. Dr. Alexander Pavlovichev, Russian Research Center "Kurchatov Institute," Institute of Nuclear Reactors, VVER Division, VVER Physics Department, 123182, Kurchatov Square, 1, Moscow, Russia

44. K. L. Peddicord, Associate Vice Chancellor, Texas A\&M University, 120 Zachry, College Station, TX 77843-3133

45. G. Radulescu, Framatom Cogema Fuels, 1261 Town Center Drive, MS-423, Las Vegas, Nevada 89143 
46. J. Thompson, Office of Fissile Materials Disposition, U.S. Department of Energy, NN-61, 1000 Independence Avenue SW, Washington, DC 20585

47. F. Trumble, Westinghouse Savannah River Company, Building 730R, Room 3402, WSRC, Aiken, SC 29808

48. R. H. Clark, Duke/Cogema/Stone \& Webster, 400 South Tryon Street, WC-32G, P.O. Box 1004, Charlotte, NC 28202

49. S. Nesbit, Duke/Cogema/Stone \& Webster, 400 South Tryon Street, WC-32G, P.O. Box 1004, Charlotte, NC 28202

50. M. S. Chatterton, Office of Nuclear Reactor Regulation, MS O10B3, U.S. Nuclear Regulatory Commission, Washington, DC 20555-0001

51. R. W. Lee, Office of Nuclear Reactor Regulation, MS O10B3, U.S. Nuclear Regulatory Commission, Washington, DC 20555-0001

52. U. Shoop, Office of Nuclear Reactor Regulation, MS O10B3, U.S. Nuclear Regulatory Commission, Washington, DC 20555-0001

53. Aldo Ferri, Scandpower, Inc., 101 Lakeforest Blvd., Suite 340, Gaithersburg, MD 20877

54. Nagao Ogawa; Director and General Manager; Plant Engineering Department; Nuclear Power Engineering Corporation; Shuwa-Kamiyacho Building, 2F; 3-13, 4-Chome Toranomon; Minato-Ku, Tokyo 105-0001, Japan

55. Dr. Kiyonori Aratani; Surplus Weapons Plutonium Disposition Group; International Cooperation and Nuclear Material Control Division; Japan Nuclear Cycle Development Institute; 4-49 Muramatsu, Tokai-mura, Naka-gun, Ibaraki-ken, Japan

56. Boris E. Volkov; Head of Division; EDO Gidropress; 21 Ordzhonikidze Street; Podolsk, Moscow District, Russia 142103

57. Dr. Alexandre Ermolaev; Balakovo Nuclear Power Plant, Saratov Region, Balakovo-26, Russia, 413866 